Occupational Mobility at Migration - Evidence from Spain

by Mikolaj Stanek and Alberto Veira Ramos
Centre for Social Studies/ University of Coimbra; University of Madrid

Sociological Research Online, 18 (4) 16

10.5153/sro.3134

Received: 25 Jan 2012 Accepted: 26 Jun 2013 Published: 30 Nov 2013

\title{
Abstract
}

This article provides insight into the determinants of occupational mobility recorded for immigrants between their last job in the region of origin and their first job in Spain. Multinomial and bivariate logistic regression models are applied to identify the strongest predictors of upward and downward mobility when immigrants move from one country's labour market to another. This study's empirical analysis was
out using data from the Spanish National Immigrant Survey of 2007 . Our results show that ethnic segmentation in the Spanish labour market negatively affects the occupational mobility of immigrants. Secondly, we observe that non EU15 immigrants are at higher risk of downward mobility. Thirdly, higher
levels of education offer protection against downward mobility and increase the chance for upgrading. relatives who reside in the destination country increases the risk of occupational downgrading and reduces the possibility of upward mobility.

Keywords: Migration Occupational Mobility, Spain, Labour Market Segmentation, Human Capital, Social Capital, Gender Gap

Introduction

$\mathbf{1 . 1}$ In the late 1980s, in keeping with the general trend observed among Mediterranean countries, Spain

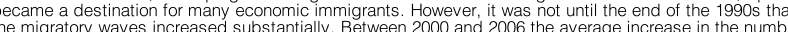
of foreigners migrating to Spain was nearly 570,000 per year. As a result, foreigners currently represent
over twelve percent of the country's total population (Cebolla \& González-Ferrer 2013). This massive inflow of immigrants had a significant impact on the Spanish economy and on the structure of its labour
market. It has been estimated that between 2000 and 2005 up to 50 percent of the growth in Spanish GDP was generated by immigrant workers and of the eight million new jobs created between 1994 and 2007 , two and a halt million were occupied by immigrant workers (Cachón 2009). Thus, immigrants played 1.2 This boom in the immigrant population and the changing ethnic structure of the labour market has
generated considerable interest among policy makers and social scientists. In recent years, various generated considerable interest among policy makers and social scientists. In recent years, various 作 observed that upon arrival, immigrants usually do worse than natives with similar socio-demographic (Cencteristics and alve

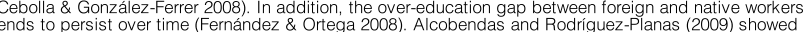
that although immigrants begin to experience upward mobility within the first five years of residence in Spain, their occupational status never fully converges with that of Spaniards with comparable skills. foreign and native workers over the first five years of residence in Spain, the disparity does not disappear completely.

1.3 Although the patterns of post-migratory occupational adjustment seem to be fairly clear, there are phenomenon of occupational mobility that occurs when foreign workers move from their country of orig lo a host country. Therefore the purpose of this article is to assess the occupational mobility patterns of occupational mobility among immigrant workers in the Spanish labour market by comparing the status of their last job in the country of origin to that of their first job in Spain. We use basic descriptive statistics and logistic regression models to examine the impact of several demographic, social and contextual
factors on occupational mobility at migration and to test several hypotheses that are presented in the
following section.

Empirical background and hypotheses

2.1 It was Chiswick (1977) who, in his seminal study on assimilation of immigrants in the United States, lirst observed that occupational mobility between the country of origin and the country of destination lakes a U-shaped pattern: downward mobility in the first job after migration, followed by an improvement showing that newly arrived immigrants are very likely to suffer occupational downgrading when they reach
the destination country (Rooth \& Ekberg 2006; Redstone Akresh 2008). In our study, however, due to data (1) occupational mobility between the last job in the country of origin and the first job attained upon arrival to
onition Spain.

2.2 Several studies have revealed that occupational mobility depends on an immigrant's individual qualities as well as contextual variables related to the characteristics of the labour market and the socie upon migration is affected by gender, structural and institutional constraints, as well as individuacharacteristics such as human capital and social capital. In the following paragraphs we establish ou

Gender 2.3 Cross-sectional studies in different geographical contexts revealed that among immigrants women
experience a greater occupational setback than men after moving to a foreign country (Raaiman $\&$

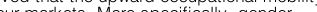
segmentation relegates the female immigrant population to a narrow range of jobs, some of which have very limited possibilities for upward mobility given the type of demand and the organisation of the work ( eproductive roles in households makes it more difficult for the female population to achieve vertical mobility or to maintain their occupational status upon migration; not only do women have to reconcile their

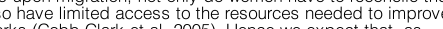
occurs in other receiving countries immigrant women in $\mathrm{Spain}$ will be at greater risk of suffering downward occupational mobility than men (hypothesis $\mathrm{H} 1 \mathrm{a}$ ) and have a lower probability of experiencing

Institutional factors

2.4 Institutional factors and, more specifically, migration policies should be taken into account when
nnalysing how newly arrived immigrants locate themselves in the Spanish occupational structure. During the bis hation period covered by our study, nationals of the old European Union mema enjoyed the same rights and conditions as Spanish workers in terms of mobility within EU boundaries and
work opportunities. Free movement of the labour force includes the right to seek employment in another
member country, to move there to search for employment, to reside there for the purpose of employment, member country, to move there to search for employment, to reside there for the purpose of employmen
and to remain there following the completion of employment. This contrasts with the severe restrictions and to remain there following the completion of employment. This contrasts with the severe restrictions
faced by immigrants from non-EU15 countries, including those from the new accession member states (EU10) ${ }^{[2]}$. Over the last two decades, Spanish authorities have implemented policies in order to organise immigration flows so that they would both meet the needs of the labour market and at the same time protect native workers (Ferrero-Turrión \& López-Sala 2009). Immigrants must follow a complex abtain their first work permits. Initial work permits are valid only for a specific economic sector and obtain their tirst work permits. Initial work permits are valid only for a specific economic sector and
territory. Restrictive migratory policies coupled with strong demand for foreign workers within the Spanish
economy and lax control of the internal labour market resulted in an increasing number of irregular . Most of the non-EU15 immints entered Spain irregularly - or Spain (Cebol country without a valid permit after entering with a short-term visa and later received legal status throug regularisation programmes (Bemardi et al. 2011; Sabater \& Domingo 2012). Furthermore, during the prestige and low-wage occupations in the secondary labour market ( (achón 2009; Stanek 2011). Therefore, in our analysis we expect immigrants from outside the EU15 to have higher risks of occupational downgrading upon migration (H2a) and lower proba
situation $(H 2 b)$ compared to immigrants from the EU15 countries.

Structural factors

2.5 Another factor that affects occupational mobility in Spain is its segmented labour market (Polavieja
2003). Segmentation theory argues that the labour market is divided into at least two different segments, 
each with its own structure, allocation rules and occupational mobility mechanisms. The core/primary
segment offers jobs with relatively high wages, acceptable working conditions and possibilities of segment offers jobs with relatively high wages, acceptable working conditions and possibilities of
occupational promotion, whereas jobs in the periphery/secondary segment are low paid, unstable, menil labour-intensive and with little room for occupational mobility (Piore 1979). These features make it difficult for employers to attract native workers to secondary segment jobs and create continuous demand in
advanced economies for workers from less industrialised countries. Immigrants tend to be channelled into low paid jobs in specific labour intensive economic sectors regardless of their skill level and previous work experience. This explains why, as a general pattern, most immigrants suffer occupational
downgrading at migration (Pedace 2006 )

2.6 The history of economic transformations that have been taking place for last few decades in Spain suggest that labour market segmentation is a factor that has greatly conditioned labour force mobility in sectors such as hospitality services, construction and agriculture (Garrido et al. 2010). Expansion of these branches of the economy has resulted in a considerable increase in the demand for low-skilled manual workers. Simultaneously, educational expansion has improved the occupational positions held by Spanis left many low-skill iobs vacant (Domingo et al. 2007). These transformations have concentrated and clustered immigrants in the lowest positions of the least appealing economic sectors of the Spanish economy (Cachon 2009). (the need to fill the lower positions in the labour market is one of the key factors driving the occupational distribution of immigrants in Spain, we hypothesise is on a to suffer downward mobility upon migration (H3a) and less likely to experience upward mobility (H3b). We also expect that immigrants who arrived in Spain during the period of major economic expansion (20022007) are at higher risk of experiencing an occupational downgrade (Haj) and less likely to improve their

Human capital

2.7 From the human capital perspective, occupational mobility varies in relation to individual productivity

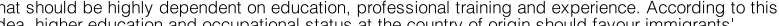
integration into the labour market of the destination country. However, existing relevant literature on this topic argues that human capital is often country-specific and not perfectly portable or transferable to the host country's labour market (Friedberg 2000; Gathmann 2010). With respect to formal education it is first-world country because of buratic impediments ${ }^{3]}$ (Redstone Akresh 2006: Reyneri \& Fullin 2011). Similarly, occupational skills and experience obtained in less technologically advanced countries are rarely transferable to more developed economies (Chiswick et al. 2003). In fact it has been observed hreater risk of downward mobility as they are more likely to find that some of their professional skills of less value in the destination country (Chiswick et al. 2005). Another reason to expect a limited return on human capital after migration is the immigrant's poor knowledge of the recruitment channels and the
general functioning of the host country's labour market institutions. This often forces immigrants to accept
jobs below their formal qualifications and professional experience (Reyneri \& Fullin 2011).

2.8 As argued above, the effect of human capital on occupational mobility at migration is very complex
However here we presume a positive effect of education but no returns on previous occupational experience. Regarding education effect, substantial and widespread empirical evidence confirm that higher educational level has a significant and positive association with obtaining higher ranked
occupations after arrival (McAllister 1995; Raijman \& Semyonov 1995; Redstone Akresh 2006). This relation is usually explained by the fact that employers value education because they enhance employe education is strongly linked to a higher risk of working in immigrant occupational niches, and working in immigrant niches is related to a higher risk of occupational downgrading (Veira et al. 2011). Concerning paragraph which hold that migration generally implies a devaluation of job specific human capital, thus, educational level are less likely to suffer occupational downgrading ( $\mathrm{H}$ (5) and more likely to experience expected to suffer a greater risk of downward mobility (H6a) and less likely to experience upward mobility (H6b)

2.9 Finally, language proficiency is generally seen as one of the most important dimensions of human being able to communicate in the host country's language in order to facilitate transferring skills from the or mitigates against

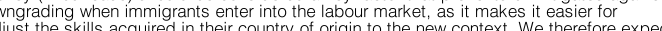
hat Spanish speaking workers from Latin America would be less prone to suffer downward mobility (H7)
hat (H7b)

\section{Social capital}

2.10 Our analysis also takes into account the social capital of immigrants derived from personal contacts at arrival. Social capital is usually defined as the ability of individuals and groups to secure specific capital can be converted into information, referrals (to accommodation, for example) or direct financia help, which reduces the costs of migration and adaptation into the host society and labour market (the occupational attainments of immigrants is still unclear. On the one hand, a number of studies suggest
that having friends and relatives with migratory experience improves the efficiency and effectiveness of an immigrant's job search because they provide more accurate information on employment opportun
hiring practices and labour-market conditions in the host country (Nee $\&$ Sanders 201 ; A A uilera $\&$
Massey 2003) In addition, it has been claimed that this kind of social capital is particularly useful Massey 2003). In addition, it has been claimed that this kind of social capital is particularly useful immediately after arrival, when the immigrant lacks other social resources, as friends and relatives filter
job opportunities and reserve better ones for members of their own social networks (Mullan 1989; Pascual

2.11 Conversely, some scholars have highlighted the detrimental effect of using networks of relatives and information is being circulated. and these sources therefore may provide limited information on labour market opportunities (Lancee 2010). Dependence on ethnically or socially homogenous networks may channel newly arrived immigrants into jobs (mainly in the ethnic niches), which are characterised by low
status, low wages and poor working conditions (Nee \& Sanders 2001: Kazemipur 2006). Therefore, some researchers suggest that social networks provide a temporary shelter against unemployment for
newcomers, but the trade-off is a high risk of occupational downgrading (Kalter \& Kogan 2011).

2.12 Given the absence of clear empirical evidence on the effects of social capital on labour market attainments for newly arrived immigrants, our expectations for immigrants who rely on friends and
relatives to find their first job are ambivalent (H8a for downward mobility and H8b for upward mobility). However, we argue that having a contract (verbal or formal) with a Spanish employer before migration will
reduce the risk of losing occupational status (H9a) and increase the possibility of upward mobility (H9b)

Table 1: Hypotheses concerning occupational mobility upon migration to Spain 


\begin{tabular}{|c|c|c|}
\hline H1a & \multirow{2}{*}{ 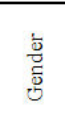 } & $\begin{array}{l}\text { Immigrant women in Spain are at greater risk of suffering downward occupational } \\
\text { mobility than men }\end{array}$ \\
\hline $\mathrm{H} 1 \mathrm{~b}$ & & $\begin{array}{l}\text { Immigrant women in Spain have a lower probability of experiencing upward mobility } \\
\text { than men }\end{array}$ \\
\hline $\mathrm{H} 2 \mathrm{a}$ & \multirow{2}{*}{ 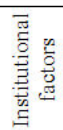 } & $\begin{array}{l}\text { Immigrant workers from the EU15 countries have lower risks of occupational } \\
\text { downgrading compared to immigrants from outside the EU15 cluster }\end{array}$ \\
\hline $\mathrm{H} 2 \mathrm{~b}$ & & $\begin{array}{l}\text { Immigrant workers from the EU15 countries have better odds of improving their } \\
\text { occupational situation compared to immigrants from outside the EU15 cluster }\end{array}$ \\
\hline $\mathrm{H} 3 \mathrm{a}$ & \multirow{4}{*}{ 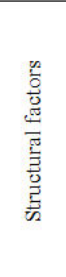 } & $\begin{array}{l}\text { Immigrants who find their first job in Spain in economic sectors that constitute ethnic } \\
\text { niches for foreign workers (namely agriculture, construction, hospitality services and } \\
\text { domestic work) are more likely to suffer downward mobility upon migration }\end{array}$ \\
\hline $\mathrm{H} 3 \mathrm{~b}$ & & $\begin{array}{l}\text { Immigrants who find their first job in Spain in economic sectors that constitute ethnic } \\
\text { niches for foreign workers (namely agriculture, construction, hospitality services and } \\
\text { domestic work) are less likely to experience upward mobility }\end{array}$ \\
\hline $\mathrm{H} 4 \mathrm{a}$ & & $\begin{array}{l}\text { Immigrants who arrived in Spain during the period of major economic expansion } \\
(2002-2007) \text { are at higher risk of experiencing an occupational downgrade }\end{array}$ \\
\hline $\mathrm{H} 4 \mathrm{~b}$ & & $\begin{array}{l}\text { Immigrants who arrived in Spain during the period of major economic expansion } \\
(2002-2007) \text { are less likely to improve their occupational status }\end{array}$ \\
\hline $\mathrm{H} 5 \mathrm{a}$ & \multirow{6}{*}{ 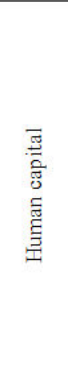 } & Higher levels of education decrease the risk of downward mobility \\
\hline $\mathrm{H} 5 \mathrm{~b}$ & & Higher levels of education increase the likelihood of occupational upgrading \\
\hline $\mathrm{H} 6 \mathrm{a}$ & & $\begin{array}{l}\text { Immigrants with a higher occupational profile in their country of origin will be more } \\
\text { likely to suffer downward mobility }\end{array}$ \\
\hline $\mathrm{H} 6 \mathrm{~b}$ & & $\begin{array}{l}\text { Immigrants with a higher occupational profile in their country of origin will be less } \\
\text { likely to experience upward mobility }\end{array}$ \\
\hline $\mathrm{H} 7 \mathrm{a}$ & & $\begin{array}{l}\text { Spanish speaking immigrant workers from Latin America are less prone to suffer } \\
\text { downward mobility at migration than other non-EU15 immigrant groups }\end{array}$ \\
\hline $\mathrm{H} 7 \mathrm{~b}$ & & $\begin{array}{l}\text { Spanish speaking immigrant workers from Latin America are more likely to improve } \\
\text { their occupational position at migration than other non-EU15 immigrant groups }\end{array}$ \\
\hline $\mathrm{H} 8 \mathrm{a}$ & \multirow{4}{*}{ 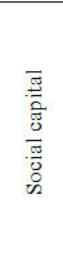 } & $\begin{array}{l}\text { Our expectations for immigrants who rely on friends and relatives to find their first job } \\
\text { are ambivalent conceming their likelihood of downward mobility }\end{array}$ \\
\hline $\mathrm{H} 8 \mathrm{~b}$ & & $\begin{array}{l}\text { Our expectations for immigrants who rely on friends and relatives to find their first job } \\
\text { are ambivalent conceming their chances of upward mobility }\end{array}$ \\
\hline H9a & & $\begin{array}{l}\text { Having a contract (verbal or formal) with a Spanish employer before migration is } \\
\text { expected to reduce the risk of losing occupational status }\end{array}$ \\
\hline $\mathrm{H} 9 \mathrm{~b}$ & & $\begin{array}{l}\text { Having a contract (verbal or formal) with a Spanish employer before migration is } \\
\text { expected to increase the possibility of upward mobility }\end{array}$ \\
\hline
\end{tabular}

Data and methods 3.1 The analyses presented in this article rely on the National Immigrant Survey (NIS-2007) data set
conducted by the Spanish National Statistics Institute. Data were collected between November 2006 and
Fobruary 2007 from (a) of origin and year of arrival. It also collected data on their occupational backgrounds in the country of origin and on the first job attained in Spain, enabling us to assess whether immigrants experienced

3.2 For the sake of analytical consistency, we reduced the original NIS-2007 sample to 3,506 individuals. We selected only immigrants who reported the occupation and branch of industry of the last job they held before migrating, and the first job they attained in Spain. The population analysed was limited to tisose

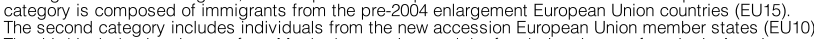
The third includes immigrants from Maghreb countries; and the fourth, immigrants from Latin America. There were too few cases from Sub-Saharian Africa and Asia to consider them as separate regions. We
also limited the sample to those who arrived between 1985 and 2007 (although more than 85 percent arrived after 1996 and almost 60 percent after 2001) [4] $^{4]}$. Furthermore we focused on immigrants who were already fully economically active at the time of migration that is 25 to 55 years old at the moment of the Finally we also excluded individuals who continued to work for the same employer after migrating (i.e.
fing those posted to Spain as a new work destination).

3.3 Our dependent variable, 'Occupational mobility', was created using two other variables containing
information on the last occupation immigrants had in their country of origin and the first occupation they information on the last occupation immigrants had in their country of origin and the first occupation they
found after their arrival to Spain. To classify workers in comparable categories we employed the European Socio-economic Classification (ESeC schema). The ESeC schema was established to operationalise Occupations ( $\mathrm{SCO}-8)^{[5]}$. Therefore it is particularly useful in cases of cross-country studies (Rose \& Harrison 2007). The ESeC is based on theoretical assumptions derived from the Erikson-GoldthorpePortocarero (EGP) class-scheme (Erikson \& Goldthorpe 1992) in which socio-economic positions are defined by the nature of employment relations. Employment relations in the ESeC are defined considering two main dimensions: the level of human asset specificity $[6]$ a given job requires from the worker and how nalyses, the ESeC schema was reordered according to the mean earnings of each occupational category in order adapt it to the peculiarities of the Spanish labour market. Because immigrants employed in lower clerical occupations, we changed their positions on our ranking scale. In addition, as the number of seltemployed immigrants in agriculture was very small we merged this category with that of small employers and self-employed workers in non-agricultural economic sectors. Table 2 provides a detailed view of the

3.4 The independent variables are 'Age at arrival in Spain', 'Gender', 'Region of Origin', 'Period of arrival in Spain, "ndustrial sector of the first job in Spain', 'Contract upon arrival, Job search aided by friends and metric variable ranging from 25 to 55 . Variables such as 'Period of arrival' and 'Industrial sector of the first job in Spain' measure the effect of structural and contextual constraints, while the education and 'Contract at arrival' is a dichotomous variable distinguishing between those who had a contract (written or verbal) with a Spanish employer before they arrived in Spain. 'Job search aided by friends and relatives' indicates whether or not immigrants obtained their first job in Spain through the assistance of friends or relatives who were already residing in Spain.

3.5 Our next step was to divide our sample into two sub-samples, distinguishing immigrants who had semi-and non-skilled occupations in their country of origin ( 1,039 cases) from the rest $(2,467$ individuals). In the case of those who were employed in other occupations before they moved to Spain we sought to mobility [7] However for those who had semi- and non skilled occupations in their countries of oigin and mobility . However, for those who had semi- and non-skilled occupations in their countries of origin and
therefore could not experience downward mobility, our aim was to identify which variables significantly therefore could not experience downward mased the likelinood of upward mobility.
increas

Table 2: Description of the modified European Socio-economic Classification (ESeC) 


\begin{tabular}{|c|c|c|c|c|c|}
\hline & Modified common term & Modified ESeC class & Most common occupations & & Original ESeC common term \\
\hline 1 & Higher salariat & $\begin{array}{l}\text { Large employers, higher grade } \\
\text { professional, higher grade } \\
\text { administrative and managerial } \\
\text { occupations }\end{array}$ & $\begin{array}{l}\text { employer (>9 employees), engineer, } \\
\text { financial manager, medical doctor }\end{array}$ & 1 & Higher salariat \\
\hline 2 & Lower salariat & $\begin{array}{l}\text { Lower grade professional, } \\
\text { administrative and managerial } \\
\text { occupations }\end{array}$ & $\begin{array}{l}\text { school-teacher, nurse, computer } \\
\text { technician }\end{array}$ & 2 & Lower salariat \\
\hline 3 & $\begin{array}{l}\text { Higher grade white collar } \\
\text { workers }\end{array}$ & $\begin{array}{l}\text { Mostly clerical occupations and } \\
\text { administrative assistants }\end{array}$ & business secretary, office worker & 3 & Higher grade white collar workers \\
\hline 4 & $\begin{array}{l}\text { Small employer \& self } \\
\text { employed occupations } \\
\text { (categories } 4 \text { and } 5 \text { in the } \\
\text { original ESeC merged) }\end{array}$ & $\begin{array}{l}\text { Small employers and independent } \\
\text { workers in non-professional } \\
\text { occupations }\end{array}$ & $\begin{array}{l}\text { shopkeeper and other small business } \\
\text { owner ( }<10 \text { employees), independent } \\
\text { craft worker, farm owner }\end{array}$ & 4 & $\begin{array}{l}\text { Small employer and self employed } \\
\text { occupations (except agriculture, etc.) } \\
\text { Small employer and self employed } \\
\text { occupations (agriculture, etc.) }\end{array}$ \\
\hline 5 & $\begin{array}{l}\text { Higher grade blue collar \& } \\
\text { skilled workers (categories } 6 \\
\text { and } 8 \text { in the original ESeC } \\
\text { merged) }\end{array}$ & $\begin{array}{l}\text { Lower supervisory, lower technicians } \\
\text { and manual workers with greater } \\
\text { organisational skills }\end{array}$ & $\begin{array}{l}\text { foreman, railroad worker, car } \\
\text { mechanic, plumber, }\end{array}$ & 6 & $\begin{array}{l}\text { Higher grade blue collar workers } \\
\text { Skilled workers }\end{array}$ \\
\hline 6 & $\begin{array}{l}\text { Lower grade white collar } \\
\text { workers }\end{array}$ & $\begin{array}{l}\text { Lower services, sales and clerical } \\
\text { occupations }\end{array}$ & retail assistant, kindergarten assistant & 7 & Lower grade white collar workers \\
\hline 7 & Semi- and non-skilled workers & $\begin{array}{l}\text { Routine occupations that require low } \\
\text { skills needed and a high degree of } \\
\text { supervision }\end{array}$ & $\begin{array}{l}\text { domestic worker, truck driver, } \\
\text { agricultural labourers, assemblers }\end{array}$ & 9 & Semi- and non-skilled workers \\
\hline
\end{tabular}

3.6 To analyse the determinants of occupational mobility experienced by immigrants who were employed with 'no mobility' as a category of reference. In the case of those who were employed in semand non-skilled occupations in their country of origin we applied a binomial logistic regression, since this category of workers has no in all variables, we have implemented reduced models in order to identify the relative impact of three groups
of variables: variables reflecting the structural and institutional factors, variables related to human capital
and variables accounting for the effect of social capital.

\section{Descriptive analysis}

4.1 Table 3 describes some of the relevant characteristics of the whole sample and the two subsamples and the a in our sludy. The data reveal that the proportion of women is slightly higher than that of men percent from the EU10 countries, 10.8 percent from EU15 countries and 9.5 percent from the Maghreb region of North Africa, mainly Morocco. Over 88 percent arrived in Spain between 1997 and 2007. Sample

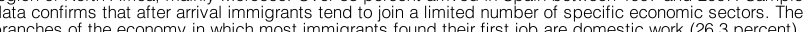

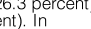
contrast, only 14.9 percent found their first job in finance, health care or education.

4.2 When occupational status prior to migration is taken into account, as much as 29.6 percent of perigrants were employed as semi- and non-skilled workers in their country of origin. Another 19.1 percent were occupied as higher grade blue collar and skilled workers, and 19.0 percent worked in low

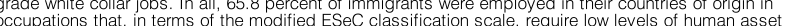
specificity and are easily monitored by employers. In terms of education, only 18.7 percent of immigrants have a university degree and 56.6 percent completed secondary education. Regarding social capital it must be noted that 83.7 percent arrived in Spain with no formal or informal (verbal) contract. However, a

Table 3: Descriptive statistics of the sampled population's main characteristics

\begin{tabular}{|c|c|c|c|c|c|c|}
\hline \multirow[t]{2}{*}{ Variables } & \multicolumn{2}{|c|}{$\begin{array}{c}\text { skilled manual } \\
\text { and non-manual }\end{array}$} & \multicolumn{2}{|c|}{$\begin{array}{l}\text { semi- and non- } \\
\text { skilled }\end{array}$} & \multicolumn{2}{|c|}{ Total } \\
\hline & $\mathrm{N}$ & $\%$ & $\mathrm{~N}$ & $\%$ & $\mathrm{~N}$ & $\%$ \\
\hline Age at arrival in Spain & 2,467 & $\begin{array}{c}33.8 \\
\text { (mean) }\end{array}$ & 1,039 & $\begin{array}{c}33.4 \\
(\text { mean })\end{array}$ & 3,506 & $\begin{array}{c}33.7 \\
(\text { mean) }\end{array}$ \\
\hline \multicolumn{7}{|l|}{ Gender } \\
\hline Male & 1,152 & 46.7 & 424 & 40.8 & 1,576 & 45.0 \\
\hline Female & 1,315 & 53.3 & 615 & 59.2 & 1,930 & 55.0 \\
\hline \multicolumn{7}{|l|}{ Origin } \\
\hline EU15 & 281 & 11.4 & 96 & 9.2 & 377 & 10.8 \\
\hline EU10 & 622 & 25.2 & 301 & 29.0 & 923 & 26.3 \\
\hline Maghreb & 198 & 8.0 & 135 & 13.0 & 333 & 9.5 \\
\hline Latin America & 1,366 & 55.4 & 507 & 48.8 & 1,873 & 53.4 \\
\hline \multicolumn{7}{|l|}{ Branch of industry of first job in Spain } \\
\hline Agriculture & 281 & 11.4 & 232 & 22.3 & 513 & 14.6 \\
\hline Domestic work & 678 & 27.5 & 243 & 23.4 & 921 & 26.3 \\
\hline Hospitality sector & 284 & 11.5 & 116 & 11.2 & 400 & 11.4 \\
\hline Construction & 404 & 16.4 & 194 & 18.7 & 598 & 17.1 \\
\hline Manufacturing industry & 213 & 8.6 & 71 & 6.8 & 284 & 8.1 \\
\hline Financial services & 162 & 6.6 & 42 & 4.0 & 204 & 5.8 \\
\hline Health care, education and public sector & 197 & 8.0 & 51 & 4.9 & 248 & 7.1 \\
\hline Commerce, transport and communications & 248 & 10.1 & 90 & 8.7 & 338 & 9.6 \\
\hline \multicolumn{7}{|l|}{ Period of arrival in Spain } \\
\hline $1985-1996$ & 270 & 10.9 & 88 & 8.5 & 358 & 10.2 \\
\hline 1997-2001 & 1,009 & 40.9 & 433 & 41.7 & 1,442 & 41.1 \\
\hline $2002-2007$ & 1,188 & 48.2 & 518 & 49.9 & 1,706 & 48.7 \\
\hline \multicolumn{7}{|l|}{ Level of education } \\
\hline Primary or less & 470 & 19.1 & 396 & 38.1 & 866 & 24.7 \\
\hline Secondary & 1,413 & 57.3 & 571 & 55.0 & 1,984 & 56.6 \\
\hline University & 584 & 23.7 & 72 & 6.9 & 656 & 18.7 \\
\hline \multicolumn{7}{|l|}{ Occupation at country of origin } \\
\hline Lower salariat & 374 & 15.2 & & & 374 & 10.7 \\
\hline Higher grade white collar workers & 489 & 19.8 & & & 489 & 13.9 \\
\hline Small employer and self employed & 268 & 10.9 & & & 268 & 7.6 \\
\hline Higher grade and skilled blue collar workers & 671 & 27.2 & & & 671 & 19.1 \\
\hline Lower grade white collar workers & 665 & 27.0 & & & 665 & 19.0 \\
\hline Semi- and non-skilled workers & & & 1,039 & 100.0 & 1,039 & 29.6 \\
\hline Contract at arrival & 396 & 16.1 & 177 & 17.0 & 573 & 16.3 \\
\hline $\begin{array}{l}\begin{array}{l}\text { Job search by contacts with rela tives and } \\
\text { friends }\end{array} \\
\text { fries }\end{array}$ & 1,635 & 66.3 & 759 & 73.1 & 2,394 & 68.3 \\
\hline Downward mobility & 1,691 & 68.5 & & & 1,691 & 48.2 \\
\hline Upward mobility & 200 & 8.1 & 288 & 27.7 & 488 & 13.9 \\
\hline Number of cases & 2,467 & & 1,039 & & 3,506 & \\
\hline
\end{tabular}


Table 4: Occupational change from last pre-immigration to first post-immigration job (\%)

\begin{tabular}{|c|c|c|c|c|c|c|c|c|c|}
\hline \multicolumn{10}{|c|}{ Occupation status in country of origin } \\
\hline Occupation status of first job in Spain & $\begin{array}{l}\text { Higher } \\
\text { salariat }\end{array}$ & $\begin{array}{l}\text { Lower } \\
\text { salariat }\end{array}$ & $\begin{array}{c}\text { Higher grade } \\
\text { white collar } \\
\text { workers }\end{array}$ & \begin{tabular}{|c|} 
Small \\
employer and \\
self \\
employed
\end{tabular} & $\begin{array}{c}\text { Higher grade } \\
\text { blue collar } \\
\text { and skilled } \\
\text { workers }\end{array}$ & $\begin{array}{c}\text { Lower grade } \\
\text { white collar } \\
\text { workers }\end{array}$ & $\begin{array}{l}\text { Semi- and } \\
\text { non-skilled } \\
\text { workers }\end{array}$ & $\begin{array}{l}\text { Total \% } \\
\text { (rows) }\end{array}$ & $\begin{array}{l}\text { Total N } \\
\text { (rows) }\end{array}$ \\
\hline Higher salariat & 30.59 & 5.88 & 1.43 & 1.87 & 0.45 & 0.90 & 0.96 & 3.48 & 131 \\
\hline Lower salariat & 7.45 & 16.31 & 1.23 & 1.87 & 0.15 & 1.20 & 0.87 & 2.90 & 109 \\
\hline Higher grade white collar workers & 6.27 & 8.56 & 12.88 & 2.99 & 0.75 & 3.91 & 0.87 & 4.23 & 159 \\
\hline Small employer and self employed & 5.10 & 2.14 & 2.45 & 10.82 & 3.28 & 2.41 & 3.46 & 3.62 & 136 \\
\hline Higher grade and skilled blue collar workers & 9.80 & 5.35 & 7.36 & 14.93 & 41.43 & 9.02 & 12.03 & 15.53 & 584 \\
\hline Lower grade white collar workers & 11.76 & 15.51 & 20.25 & 11.94 & 5.37 & 21.80 & 9.53 & 13.27 & 499 \\
\hline Semi- and non-skilled workers & 29.02 & 46.26 & 54.40 & 55.60 & 48.58 & 60.75 & 72.28 & 56.98 & 2,143 \\
\hline Total & 100.00 & 100.00 & 100.00 & 100.00 & 100.00 & 100.00 & 100.00 & 100.00 & 3,761 \\
\hline Total \% (columns) & 6.78 & 9.94 & 13.00 & 7.13 & 17.84 & 17.68 & 27.63 & 100.00 & \\
\hline Total N (columns) & 255 & 374 & 489 & 268 & 671 & 665 & 1,039 & & 3,761 \\
\hline Upward mobility & 0.00 & 5.88 & 2.66 & 6.72 & 4.62 & 17.44 & 27.72 & 12.98 & 488 \\
\hline No Mobility & 30.59 & 16.31 & 12.88 & 10.82 & 41.43 & 21.80 & 72.28 & 37.36 & 1,405 \\
\hline Downward mobility & 69.41 & 77.81 & 84.46 & 82.46 & 53.95 & 60.75 & 0.00 & 49.67 & 1,868 \\
\hline
\end{tabular}

Note: percentages should be read by columns

4.3 Table 4 records occupational mobility experienced by immigrants between the last job held before migration and the first job obtained in Spain. After their arrival in Spain, 49.67 percent experienced
downard adequate to their pre-migration occupational status. Another indicator demonstrating that downward mobility is the dominant trend is that although only 27.63 percent of immigrants were employed in semi-

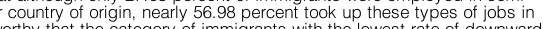
mobility is found among those who were skilled blue collar workers in their countries of origin (53.95 percent). Additionally those employed in the lowest occupational categories at origin have the highes werkers upward mos ity (ownward mobility that are highectively). The remaining categories of immigran dominated by mobility from a white collar or a skilled blue collar occupation into the position of a semi o unskilled worker, the lowest occupational category (60.75 percent of lower grade white collar employees move into unskilled occus ations and about 50 percent among the remaining categories). The only These immigrants suffer downward mobility mainly by moving into other white collar occupations, although 29.02 percent become employed as unskilled labour after arriving in Spain. Finally, it should be noted that only immigrants with the lowest occupational stalus in Multivariate analyses

5.1 This section addresses the questions and hypotheses presented above. The responses are based on designed. Findings are presented as follows: first, we report our findings concerning the gender gap; then variables related to human capital: finally, we assess the impact of the variables associated with social variables
capital.

Gender

5.2 The results corroborate our hypotheses concerning the existence of a gender gap ( $\mathrm{H} 1 \mathrm{a}$ and $\mathrm{H1b}$ ). mobility than men. It must be noted that the results for upward mobility among workers in skilled manual and non-manual occupations (Table 5) show that the gender gap effect seems to tade away (coefficients

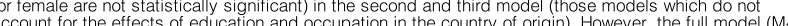
for upward mobility among workers in skilled manual and non-manual occupations and all models for upward mobility among workers in semi- and non-skit Institutional factors

5.3 Coefficients shown in Table 5 for immigrants who were workers in skilled manual and non-manual occupations before migration clearly indicate that EU15 immigrants sutfer lower risks of downward argues that a more tavourable legal context helps workers from other EU15 countries retain their occupational status, since non EU15 immigrants face significant legal obstacles to their full incorporation into the regular labour market. This legal barrier greatly restincts the access of non-EU15 workers to jobs ncreasing the odds that they will experience downward mobility. Regarding upward mobility however there are no clear signs that workers from EU15 countries have greater chances than non-EU15 workers

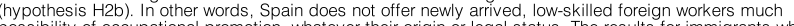
worked in semi- and non-skilled occupations in their country of origin, shown in Table 6 do not indicate that immigrants arriving from the EU15 are more likely to experience upward mobility. However, we cannot
rule out the possibility that this result is due to the fact that our sample only contained a small number of semi- and non-skilled workers coming from the EU15.

5.4 Assessing the existence of inequalities among non-EU15 immigrants, we observed that those from the Maghreb region are most likely to sufter downward mobility. At first glance, they also seem to have industrial sector, suggesting that semi- and non-skilled workers from the Maghreb tend to concentrate in sectors offering fewer chances for upward mobility.

\section{Structural factor}

5.5 Our results presented in Table 5 and Table 6 confirm that occupational mobility is clearly dependent hypotheses $\mathrm{H} 3 \mathrm{a}$, economic sectors in which immigrant labour tends to concentrate such as domestic work, agriculture or hospitality are more likely to penalise recently arrived immigrants with downward
mobility. However, this does not apply to the construction sector which is one of the four man economic activities where immigrant labour concentrates in Spain (Stanek \& Veira 2012). This sector seems to be, along with the manufacturing industry, a friendlier environment for foreign workers in terms of occupational

5.6 Outcomes for upward mobility (H3b) are mostly but not entirely in line with our expectations.
Immigrants who worked in semi-and non-skilled occupations prior to migration and enter into the

economic sectors in which immigrant labour tends to concentrate are least likely to achieve upward

workers in Spain. However, among those who were skilled manual and non-manyal workers before

migration and enter into the agriculture and hospitality sectors the chances of achieving upward mobility

is greater than for the remaining categories. These results indicate that immigrants who have prior working economic sectors than in other areas. Nonetheless, it must be emphasised that the likelihood of suffering occupational downgrading when entering these economic sectors is much higher than the odds of

experiencing upward $\mathrm{m}$

5.7 The period of arrival was not found to play a major role ( $\mathrm{H} 4 \mathrm{a}$ and $\mathrm{H} 4 \mathrm{~b}$ ). Some evidence indicates that
those who arrived most recently fare worse in terms of occupational mobility, but the available data show a limited level of statistical significance.

Table 5: Results of multinomial regression on occupational mobility for skilled manual and non-manual workers at origin (Reference category is 'no mobility') 


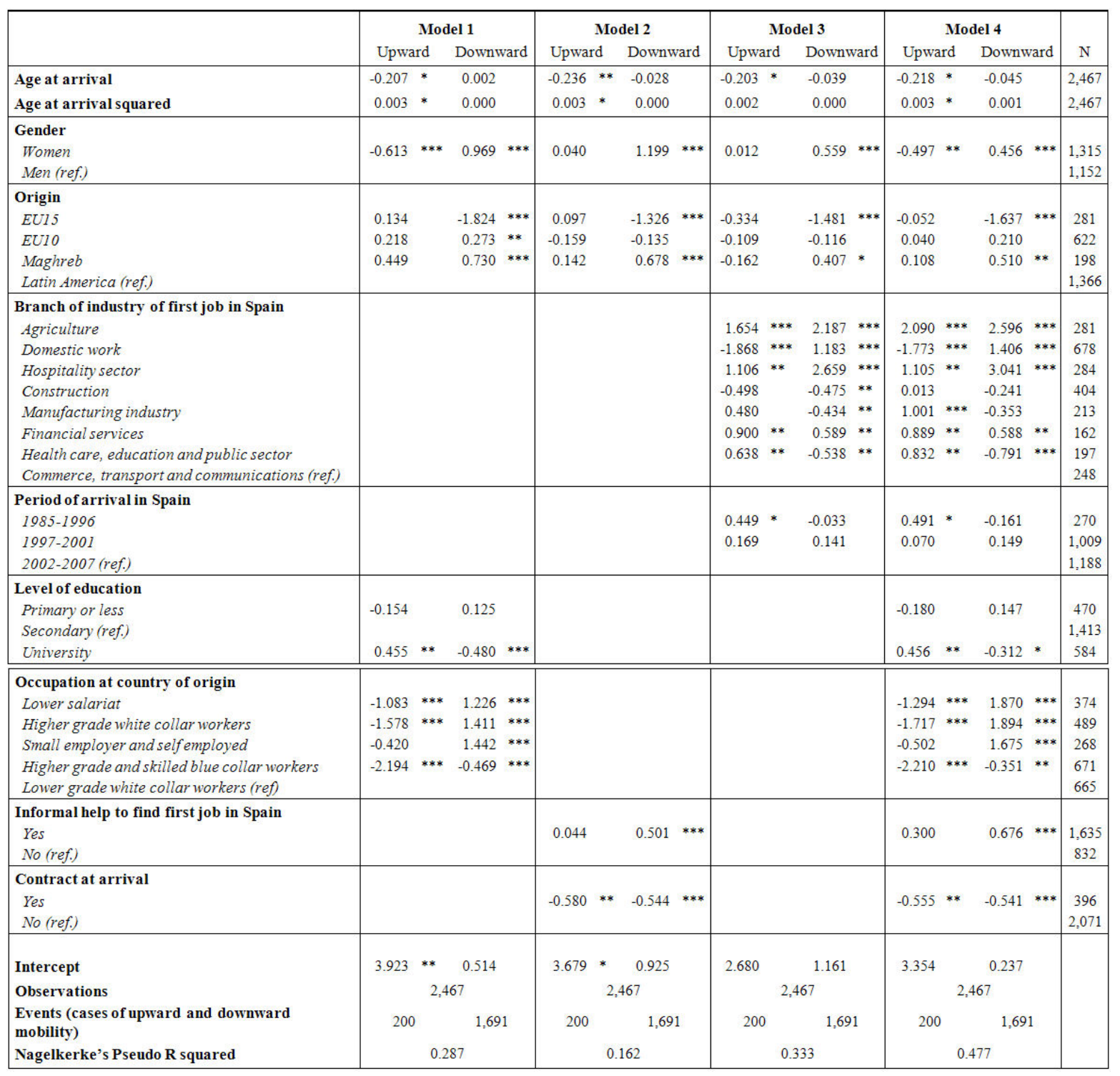

Table 6: Results of binomial regression on occupational mobility for semi- and non-skilled workers at origin (Reference 


\begin{tabular}{|c|c|c|c|c|c|}
\hline & $\begin{array}{l}\text { Model } 1 \\
\text { Upward }\end{array}$ & $\begin{array}{l}\text { Model } 2 \\
\text { Upward }\end{array}$ & $\begin{array}{l}\text { Model } 3 \\
\text { Upward }\end{array}$ & $\begin{array}{c}\text { Model } 4 \\
\text { Upward }\end{array}$ & $\mathrm{N}$ \\
\hline Age at arrival & 0.069 & 0.041 & -0.004 & -0.017 & 1,039 \\
\hline Age at arrival squared & -0.001 & 0.000 & 0.000 & 0.000 & 1,039 \\
\hline \begin{tabular}{|l|} 
Gender \\
Women \\
Men (ref.)
\end{tabular} & $-0.565 * * *$ & $-0.543 \quad * * *$ & $-0.755 * * *$ & $-0.690 * * *$ & $\begin{array}{l}424 \\
615\end{array}$ \\
\hline $\begin{array}{l}\text { Origin } \\
\text { EU15 } \\
\text { EU10 } \\
\text { Maghreb } \\
\text { Latin America (ref.) }\end{array}$ & \begin{tabular}{|l|}
0.205 \\
-0.203 \\
-0.498
\end{tabular} & $\begin{array}{l}0.085 \\
-0.235 \\
-0.592 * *\end{array}$ & $\begin{array}{r}0.160 \\
-0.092 \\
-0.180\end{array}$ & $\begin{array}{r}0.032 \\
-0.056 \\
-0.165\end{array}$ & $\begin{array}{l}96 \\
301 \\
135 \\
507\end{array}$ \\
\hline $\begin{array}{l}\text { Branch of industry of first job in Spain } \\
\text { Agriculture } \\
\text { Domestic work } \\
\text { Hospitality sector } \\
\text { Construction } \\
\text { Manufacturing industry } \\
\text { Financial services } \\
\text { Health care, education and public sector } \\
\text { Commerce, transport and communications (ref.) }\end{array}$ & & & \begin{tabular}{|rr}
-1.894 & $* * *$ \\
-0.421 & \\
-3.015 & $* * *$ \\
-0.423 & \\
0.017 & \\
-0.526 & \\
1.002 & $* *$
\end{tabular} & $\mid \begin{array}{lll}-1.809 & * * * \\
-0.492 & \\
-3.100 & * * * \\
-0.322 & \\
0.030 & \\
-0.529 & \\
0.769 & *\end{array}$ & $\begin{array}{c}232 \\
243 \\
116 \\
194 \\
71 \\
42 \\
51 \\
90\end{array}$ \\
\hline $\begin{array}{l}\text { Period of arrival in Spain } \\
1985-1996 \\
1997-2001 \\
2002-2007 \text { (ref.) }\end{array}$ & & & $\begin{array}{l}0.046 \\
0.314 *\end{array}$ & $\begin{array}{r}-0.022 \\
0.272\end{array}$ & $\begin{array}{c}88 \\
433 \\
518\end{array}$ \\
\hline $\begin{array}{l}\text { Level of education } \\
\text { Primary or less } \\
\text { Secondary (ref.) } \\
\text { University }\end{array}$ & $\begin{array}{l}0.064 \\
1.217 * * *\end{array}$ & & & $\begin{array}{l}0.132 \\
1.055^{* * *}\end{array}$ & $\begin{array}{c}396 \\
571 \\
72\end{array}$ \\
\hline $\begin{array}{l}\text { Informal help to find first job in Spain } \\
\text { Yes } \\
\text { No (ref.) }\end{array}$ & & $-0.528 \quad * * *$ & & $-0.463 * * *$ & $\begin{array}{l}759 \\
280\end{array}$ \\
\hline $\begin{array}{l}\text { Contract at arrival } \\
\text { Yes } \\
\text { No (ref.) }\end{array}$ & & -0.036 & & -0.032 & $\begin{array}{l}177 \\
862\end{array}$ \\
\hline \begin{tabular}{|l} 
Intercept \\
Observations \\
Events (cases of upward mobility) \\
Nagelkerke's Pseudo R squared
\end{tabular} & $\begin{array}{c}-2.214 \\
1,039 \\
288 \\
0.058\end{array}$ & $\begin{array}{c}-1.149 \\
1,039 \\
288 \\
0.044\end{array}$ & $\begin{array}{c}-0.278 \\
1,039 \\
288 \\
0.210\end{array}$ & $\begin{array}{c}0.165 \\
1,039 \\
288 \\
0.234\end{array}$ & \\
\hline
\end{tabular}

\section{Human capital}

5.8 Our expectations on the effect of level of education (hypothesis H5a and H5b) were confirmed by the
results. Although no significant differences between those with secondan and thos with primany results. Although no significant differences between those with secondary and those with primary education were observed, immigrants with university education are less likely to suffer downward mobility of the last occupation held in the country of origin (hypotheses $H 6$ a and HGb), Table 5 shows that immigrants who were lower grade white collar workers in their country of origin are the most likely to
experience upward mobility after migration, and the second least likely to suffer downward mobility (after

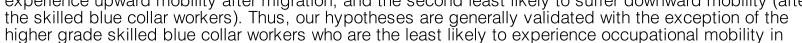
higher grade skilled blue collar workers who are the least likely to experience occupational mobility in
either direction. We believe these results indicate that immigrants employed as skilled blue collar workers in their country of origin
occupational experience.

5.9 As for our hypotheses $\mathrm{H} 7 \mathrm{a}$ and $\mathrm{H} 7 \mathrm{~b}$ concerning proficiency in the Spanish language, we have not experiencing occupational mobility, even after controlling for the branch of economy of first job in Spain. This clearly suggests that proficiency in Spanish does not offer a competitive advantage for Latin Americans in the Spanish labour market. We would argue that this may be becal

\section{Social capital}

5.10 Results clearly indicate that relying on help from friends and relatives to find the first job in Spain increases the risk of downward mobility and decreases the odds of upward mobility. We presume, resource. Even though social networks offer relatively fast and secure access to jobs after migrating, they also may discourage immigrants from undertaking other, more efficient (in the long run) strategies to search or a job. show that having a contract with a Spanish employer
likelihood of both upward and downward mobility.

Explanatory performance of models

5.11 With regard to the relative impact of structural and contextual variables versus individual characteristics such as human and social capital, a comparison between our three reduced models
indicates that the highest explained variance is provided by the model that captures the effect of the percent in the binomia first employment was found ( 33.3 percent in thed to human capital seem to be more important than social capital resources in terms of finding a first job in Spain without suffering occupational downgrading.

\section{Discussion}

6.1 This paper contributes to the existing literature on occupational mobility of immigrant workers in two ways. Frint respect our findings are consistent with results of other studies carried out in other countries (McAllister 1995; Seifert 1997; Chiswick et al. 2005; 2006). Secondly, we provide empirical evidence on the long menting debate between the two main (and orading mpfered by most immigrant workers worldwide One explanation emphasises the role played by the individual resources of immigrants and their capacities to
adapt to the demands of the host labour market while another focuses on the structural conditions of the

6.2 The former perspective explains the initial disadvantage of immigrants as a result of the mismatch between individual assets (educational level, skills and experience, proficiency in the language of the view, occupational downgrading at migration is mainly due to the lack of avajlability of employable skills in the host country labour market, often caused by the low international transferability of immigrant's human capital. The second perspective assumes that the integration of immigrants is not necessarly advanced industrial societies refuse to seek employment in the less prestigious occupations of the non-core secondary sector associated with labour-Intensive activitites, low-skill requirements and low pay, and therefore create a better positions become more widely available to autochthonous workers. Under such contexts new immigrants tend to be channelled into the secondary sector (McGovern 2007).

6.3 Our study shows that in Spain occupational mobility is mainly (though not exclusively) conditioned by ' most important role in shaping newcomers' occupational trajectories. Furthermore, we observed that immigrants who find employment in the labourkely to suffer occupational downgrading. We also saw that occupational upgrading is far more freguent among immigrants who worked in semi- and non-skilled occupations in their countries of origin (27.7 percent), than among those who were more skiled (8.1 percent), indicating that the Spanish labour marke immigrants who are the least likely to experience downward mobility are those who find jobs in the 
manufacturing and construction sectors. It must be stressed that the significant role played by structural factors in Spain may be due to the fact that, as a typically Southern European economy, it is strongly
biased towards low productivity sectors with a huge demand for elementary occupations. Therefore, thes results may not be valid for other countries where labour markets are more biased towards high skilled
jobs such as the United Kingdom, the Netherlands and Denmark (Reyneri \& Fullin 2011).

6.4 Variables related to individual characteristics are found to play a secondary but still significant role as
determinants of occupational mobility in migration to Spain. The Spanish Language proficiency of Latin The Spanish Language proficiency of Latin technician at the country of origin are attributes that contribute to mitigate the effects of the labour marke segmentation and help immigrants to retain their occupational status and even to improve it. It is important to stress that according to our results fluency in the Spanish language does not help Latin Americans with respect to EU15 workers but it does provide them with a small advantage with respect to
the other non-EU15 workers. The relative good performance in terms of finding an adequate job match of immigrants with a background as higher grade and skilled blue collar workers should be interpreted as a consequence of the high demand for this kind of labour in Spain during the decades prior to the curren the educational system did not provide adequate vocational training in the numbers required, particularly in the construction and manufacturing sectors. Therefore weaknesses in the Spanish educational system
may be behind the easier transferability of skills of lower technicians during booms in the economy.

6.5 We also found several additional factors that overlap the previously mentioned determinants and
whose main effect is to reinforce the consequences of the typically southern European labour market segmentation. At the institutional level we found evidence that European regulation securing free from third countries including those from the new accession member states (EU10) face significan obstacles to retain their occupational position. Results show clearly that non-EU15 workers suffer a higher

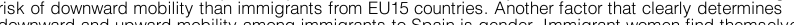
in a labour market where the occupational structure is still to a great extent segmented by gender. Thus, they are doubly disadvantaged: as immigrants and as women. Finally, there is no evidence to suggest
that social capital helps immigrants against the negative consequences of the already existing information on job opportunities seems to be rather limited. Our results demonstrate that immigrants who rely on information from relatives and friends when seeking a first job in Spain actually increase their risk of socioeconomic downgrading and block their chances of upward mobility. In this sense, our research countries were more likely to move into less desirable, low skilled and low paid jobs (Nee \& Sanders 2001). One possible explanation for this discrepancy may be that immigration to Spain is a recent phenomenon and thus new immigrants cannot rely on strong pre-existing ethnic networks a lat might

\section{Limitations}

7.1 The NIS-2007 provides the most comprehensive data source on social, demographic and economic specificity of the data on occupation we were not able to construct occupational attainment as a metric variable, according to the calegorisalion of the International Socio Economic Index (ISEl scale), which has been used in several analyses of immigrants' occupational mobility in other countries ${ }^{[8]}$ (Mulder \& van
Ham 2005: Redstone Akresh 2008). Secondly, our analysis only includes the occupational mobility of immigrants when transferred from the country of origin to Spain and does not cover further occupational trajectories. Our decision to focus on the first phase of the occupational trajectories of immigrants was matilable bytatstical data only covers short periods of time, which significantly restricts the in-ded analysis of occupational mobility. Finally, the National Immigrant Survey was conducted in 2007 and therefore does not cover the occupational situation of immigrant workers after the outbreak of the recent population, provoking a considerable slowdown in the jowth of the number of immigrants in Spain and a significant change in the social and demographic characteristics of newcomers (Cebolla \& González-
Ferrer 2013)

\section{Notes}

${ }^{1}$ The analysis of the second part of Chiswick's ' $U$ ' curve of immigrant occupational trajectory is to some Immigrants Survey was carried out), a very large proportion of interviewees were still employed in their first job.

${ }^{2}$ After the European Union enlargements in 2004 and 2007, the great majority of the EU15 countries

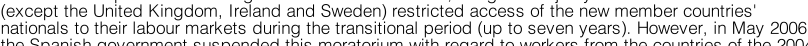
the Spanish government suspended this moratorium with regard to workers from the countries of the 2004 enlargement (Czech Republic, Estonia, Hungary, Latvia, Lithuania, Poland, Slovakia and Slovenia) and in elapsed since the opening of the Spanish labour market for workers from the 2004 enlargement countries 2006) until the moment the National Immigrants Survey was conducted (2007) we decided to include the who were granted full access two years after the completion of the survey. Therefore, in our analyses we introduce two categories of EU migrants: old member states EU nationals (EU15), which includes migrants from Austria, Belgium, Denmark, Finland, France, Germany, Greece, Ireland, Italy, Luxembourg,
Netherlands, Portugal, Sweden and the United Kingdom, and 2004 and 2007 Central and Estern European accession countries (EU10) which includes nationals of Bulgaria, Czech Republic, Estonia,
Hungary, Latvia, Lithuania, Poland, Romania, Slovakia and Slovenia.

3For instance, Raijman and Semyonov (1995) found that some educational diplomas such as those of
engineers and technicians, are more transferable than others that are more locally-specific (e.g. lawyers).

${ }^{4}$ The period covered begins in 1985 because the mid 1980s marked the beginning of the economic
migration to Spain (Arango 2004; Cachón 2009). The second dummy (1997-2001) reflects a period of economic recovery that culminated in a period of intense economic expansion at the beginning of the 21st 2011).

5 International Standard Classification of Occupations (ISCO) is a classification for organising information on occupations elaborated by the Internation
different countries for comparative purposes.

${ }^{6}$ Human asset specificity involves high amounts of job or organisation specific skills and knowledge
and/or high investments by the employer in employee's work competences (Rose \& Harrison 2007). 7 It should be noted that since immigrants who were considered higher salariat in their country of origin
( 255 cases) could not have upward mobility, they were excluded from our sample when implementing the
multinomial models.

${ }^{8}$ According to Ganzeboom et al. (1992) the ISEI scale more adequately captures variability between

occupations as it is based on a continuous measure of the socio-economic situation.

Acknowledgements This research was undertaken as part of the project Migration strategies and networks in contemporany
Spain: A research effort based on the National Immigrant Survey funded by the Spanish Ministry of
Science and Innovation (CSO 2008-03616/SOCI). We would like to thank Miguel Requena, Lorenzo Science and Innovation (CSO 2008-03616/SOCl). We would like to then

\section{References}

AGUILERA, M.B. \& Massey, D. (2003) 'Social capital and the wages of Mexican migrants: new ALBA, A., Arranz, J.M. \& Muñoz-Bullón, F. (2007) 'Exits from unemployment: Recall or new job', Labour ALCOBENDAS, M. A. \& Rodríguez-Planas, N. (2009) '"Immigrants" assimilation process in a segmented
labor market', IZA Discussion Paper Series 4394. Institute for the Study of Labor

AMUEDO-DORANTES, C. \& de la Rica, S. (2007) 'Labour market assimilation of recent immigrants in
Spain', British Journal of Industrial Relations, 45(2) p. 257-284. ARANGO, J. (2004) 'La población inmigrada en España [in Spanish: Immigrant population in Spain]',
Economistas, 99 p. 6-14. BERNARDI, F., Garrido, L. \& Miyar, M. (2011) 'The recent fast upsurge of immigrants in Spain and their
employment patterns and occupational attainment', International Migration, 49(1) p. 148-187. CACHÓN, L. (2009) La 'España inmigrante': marco discriminatorio, mercado de trabajo y políticas de
integración (in Spanish: Migrant Spain'. discriminatory framework, labour market and integration policies. Barcelona: Anthropos Editorial.

CARBALLO-CRUZ, F. (2011) 'Causes and consequences of the Spanish economic crisis: why the

CEBOLLA, H. \& González-Ferrer, A. (2008) La inmigración en España (2000-2007). De la gestión a la
integración de los inmigrantes lin Spanish: Immigration in Spain (2000-2007). From the management of integración de los inmigrantes (in Spanish: Immigration in Spain (2000-2007). From the management of
migratory flows to the integration of immigrants]. Madrid: Centro de Estudios Politicos y Constitucionales.

CEBOLLA, H. \& González-Ferrer, A. (2013) La integración inesperada [in Spanish: Unexpected integration]. Madrid: Alianza.

CHISWICK, B. (1977) 'A longitudinal analysis of the occupational mobility of immigrants', in Dennis, B.
(Ed.), Proceedings of the 30th Annual Winter Meetings (p. 20-27). Madison: Industrial Relations Research Association. 
CHISWICK, B.R., Lee, Y.L. \& Miller, P.W. (2003) 'Patterns of immigrant occupational attainment in a
longitudinal survey', International Migration, 41(4) P. 47-69. CHISWICK, B., Liang Lee, Y. \& Miller, P. W. (2005) 'Longitudinal analysis of immigrant occupational 353.

COBB-CLARK, D.A., Connolly, M.D. \& Worswick, C. (2005) 'Post-migration investments in education and
job search: a family perspective', Journal of Population Economics, 18(4) p. 663-690.

CONSTANT, A.F. \& Massey, D. (2005) 'Labor market segmentation and the earnings of German
guestworkers'. Population Research and Policy Review, 24(6) p. 5-30.

DEL RíO, C. \& Alonso-Villar, O. (2010) 'Occupational segregation of immigrant women in Spain', 2010-
165, ECINEQ Working Paper 2010-165, Society for the Study of Economic Inequality. DOMINGO, A., Gil-Alonso, F. \& Robertson, G. (2007) 'Immigration and changing labour force structure in
the Southern EUuropean Union', Population, (English Edition) 62(4) p. 709-727 ERIKSON, R. \& Goldthorpe, J.H. (1992) The Constant Flux: A Study of Class Mobility in Industrial

ESPINOSA, K. \& Massey, D.S. (1999) 'Undocumented migration and the quantity and quality of social capital. migration and transnational social spaces. Research in ethnic relations', in Pries, L. (Ed.),
Migration and Transnational Social Spaces (p. 106-137) Sidney: Ashgate Publishing. FERNÁNDEZ, C. \& Ortega, C. (2008) 'Labor market assimilation of immigrants in Spain: employment at he expense or a dob-matches?, Spanish Economical Review, 10(2) p. 83-107.

FERRERO-TURRIÓN, R. \& López-Sala, A. (2009) 'Nuevas dinámicas de gestión de las migraciones en
España: el caso de los acuerdos bilaterales de trabaiadores con países de origen lin Spanish: New España: el caso de los acuerdos bilaterales de trabajadores con países de origen [in Spanish: New dynamics of migration policies in Spain: the case of the bilateral agreements with countries of origin]'
Revista del Ministerio de Trabajo e Inmigración, 80 p. 119-132.

FRIEDBERG, R.M. (2000) 'You can't take it with you? Immigrant assimilation and the portability of human capital, Joumal or Labr

FULLER, S. \& Todd, F.M. (2012) 'Predicting immigrant employment sequences in the first years of
settlement', International Migration Review, 46(1) p. 138-190.

GANZEBOOM, H.B., De Graff, P.M., Treiman, D.J. \& De Leeuw, J. (1992) 'A standard international socio-
economic index of occupational status ', Social Science Research, 21 p. '1-56. GARRIDO, L., Miyar, M. \& Muñoz, J. (2010) 'La dinámica laboral de los inmigrantes en el cambio de fase del ciclo económico lin Spanish: Immigrants
Presupuesto y Gasto Público, 61 p. 201-221.

GATHMANN, C. (2010) 'How general is human capital? A task-based approach', Journal of Labor
Economics, 28(1) p. 1-49. GURAK, D.T. \& Caces, F. (1992) 'Networks shaping migration systems', in Kritz, M.M., Lean, L.L. \& Zlotnik, H. (Eds.), International Migration Systems: A Global Approach (p. 150-189). London: Oxford
University Press. IZQUIERDO, M., Lacuesta, A. \& Vegas, R. (2009) 'Assimilation of immigrants in Spain: A longitudina
analysis', Labour Economics, 16(6) p. 669-678.

KALTER, F. \& Kogan, I. (2011) 'Migrant networks and labour market integration of immigrants from the former Soviet Union in Germany', paper presented at the conference Migration: Economic Change, Social KAZEMIPUR, A. (2006) 'The market value of friendship: Social networks of immigrants', Canadian Ethnic
Studies Journal, 38(2) p. 47-71. LANCEE, B. (2010) 'The economic returns of immigrants' bonding and bridging social capital: the case of
the Netherlands', International Migration Review, 44(1) p. 202-226. MCALLISTER, I. (1995) 'Occupational mobility among immigrants: the impact of migration on economic
success in Australia', International Migration Review, 29(2) p. 441-468. MCGOVERN, P. (2007) 'Immigration, labour markets and employment relations: problems and prospects',

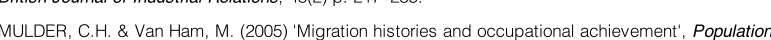
MULDER, C.H. \& Van Ham, M. (2005)
Space and Place, 11(3) p. 173-186.

MULLAN, B.P. (1989) 'The impact of social networks on the occupational status of migrants', International
Migration, 27(1) p. 69-86. NANNESTAD, P, Svendsen, G.L. \& Svendsen, G.T. (2008) 'Bridge over troubled water? Migration and
social capital', Journal of Ethnic and Migration Studies, 34(4) p. 607-631. NEE, V. \& Sanders, J. M. (2001) 'Understanding the diversity of immigrant incorporation: a forms-ofcapital model, Elhic and Racial Studies, 24(3) p. 386-411. PASCUAL, A., de Miguel, V. \& Solana, M. (2007) Redes sociales de apoyo. La inserción de la población
extranjera [In Spanish: Social support networks. Foreign population incorporation], Bilbao: Fundación PEDACE, R. (2006) 'Immigration, labor market mobility, and the earnings of native-born workers. An
occupational segmentation approach', American Journal of Economics and Sociology, 65(2) p. 313-345. PIORE, M. (1979) Birds of Passage: Migrant Labour and Industrial Societies. Cambridge: Cambridge

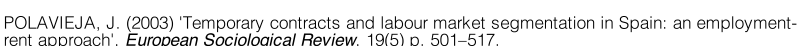
PORTES, A. (1998) 'Social capital: its origins and applications in modern sociology', Annual Review of Sociology, 24 p. 1-24.

PORTES, A. \& Sensenbrenner, Ji (1993) 'Embeddedness and immigration: notes on the social
determinants of economic action', American Journal of Sociology, 98 p. 1320-1351.

POWERS, M.G. \& Seltzer, W. (1998) 'Occupational status and mobility among undocumented immigrants POZZOLO, A. (1999) 'Human capital accumulation, social mobility and migrations', Labour, 13(3), p. 647RAIJMAN, R. \& Semyonov, M. (1995) 'Modes of labor market incorporation and occupational cost among
new immigrants to Israel', International Migration Review, 29(2) p. 375-394.

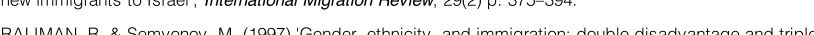
RAIJMAN, R. \& Semyonov, M. (1997) 'Gender, ethnicity, and immigration: double disadvantage and triple
disadvantage among recent immigrant women in the Israeli labor market', Gender and Society, 11(1) p.

REDSTONE AKRESH, I. (2006) 'Occupational mobility among legal immigrants to the United States',
International Migration Review, 40(4) p. 854-884. REDSTONE AKRESH, I. (2008) 'Occupational trajectories of legal US immigrants: downgrading and
recovery', Population and Development Review, 34(3) p. 435-456. REYNERI, E. \& Fullin, G. (2011) 'Labour market penalties of new immigrants in new and old receiving west
European countries', International Migration, 49(1) p. 31-57. ROOTH, D. O. \& Ekberg, J. (2006) 'Occupational mobility for immigrants in Sweden', International Migration, 44(2) p. 57-77. ROSE, D. \& Harrison, E. (2007) 'The European socio-economic classification: a new social class schema
for comparative European research', European Societies, 9 (3) p. 459-490. SABATER, A. \& Domingo, A. (2012) 'A new immigration regularization policy: the settlement program in
Spain', International Migration Review, 46(1) p. 191-220. SASSEN, S. (2001) The Global City: New York, London, Tokyo. Princeton: Princeton University Press. SEIFERT, W. (1997) 'Occupational and economic mobility and social integration of Mediterranean
migrants in Germany?', European Journal of Population, 13 p. 1-16. STANEK, M. (2011) 'Nichos étnicos y movilidad socio-ocupacional. El caso del colectivo polaco en Madrid lin Spanish: Ethnic niches and socio-occupational mobility.
Revista Española de Investigaciones Sociológicas, 135 p. 69-88.

STANEK, M. \& Veira, A. (2012) 'Ethnic niching in a segmented labour market: evidence from Spain',
Migration Letters, 10(3), p. 249-262. VEIRA, A., Stanek, M. \& Cachón, L. (2011) 'Los determinantes de concentración étnica en el mercado aboral español [in Spanish: Determinants of ethnic concentration in the Spanish labour market]', Revista
Internacional de Sociologia 69(1) p. 219-242. 